\title{
How to back up Modules with blended learning The e-Learning platform of FAME
}

\begin{abstract}
While it is a widespread belief in Hungary that higher educational institutions are still efficient with the traditional (so-called frontal teaching) approach, more and more voices are heard supporting blended learning and merely online learning. Budapest Business School (BGE), for many years now, has been favouring the latter one and thoroughly exploits its benefits during both in-house and international programmes conducted within international cooperations. The aim of this paper is to synthesize challenges BBS faced in designing and completing the blended learning programme FAME, as well as a short summary of literature that contributed to the experience.
\end{abstract}

Key words: blended learning, teaching methods, higher education projects

\section{Introduction}

Past studies have shown how blended learning slowly gained its significance in the education world. In this section we provide information about how the FAME Modules are supported by blended learning as a learning concept which combines traditional learning and e-Learning. We will focus on the planning, designing and building of our e-Learning platform, learning effectiveness, and efficiency. The goal is to get an overview of the knowledge and experience gained throughout the FAME project run by Budapest Business School (BGE) in cooperation with the Polish and British project partners.

1 PhD, associate professor, Budapest Business School; e-mail: nemeth.tamas@uni-bge.hu. DOI: http://dx.doi.org/10.31570/Prosp 2019015. 
As a consequence of the unique nature of blended learning, didactic improvements by the use of adequate mixes according to learning content and learner groups are possible. This enables individualized learning processes and self-managed learning (Graham 2006; Reiss- Steffens 2010) but following a strictly and thoroughly well-built path. This very project (FAME) was fully designed and conducted by the Budapest Business School team. ${ }^{2}$ In this paper, we will examine the e-Learning environment deployed in higher education: the choice of software, learning objectives, learning processes, learner control, learning content, interaction and instructions.

\section{Literature review}

Learning has transformed substantially during the last decades since information technology set up challenges and provided opportunities for improvements as to learning content, methodology, effectiveness and efficiency (Gunasekaran et al. 2002; Hill et al. 2013). There has been a substantial leap from traditional learning towards e-Learning environments though both show advantages and disadvantages. In a traditional learning environment, trainers/teachers can control the learning environment, use different learning methods according to the learner's needs like career plans, social context, interactional abilities and aptitude etc. (Acton et al. 2005; Hill et al. 2013). Unlike in traditional learning environments (in which learners and trainers/teachers meet faceto-face), more and more e-Learning solutions have been developed, whereby learning content is available independent of time and place. Although the first array of challenges were purely IT-based (Acton et al. 2005; Singh 2006), a new combination of both traditional and e-Learning methods emerged. These learning methods integrate traditional forms of learning with online methods and tools (Singh 2006) and started to spread widely in both corporate and educational learning (Lewis-Orton 2006; Wright et al. 2006).

Since traditional learning environments are often considered to be cost centres in corporate training and development (often employees have to travel to participate in trainings and stay away from work), e-Learning environments have been implemented in corporate education as well as in higher education. The advantages are evident: eLearning platforms offer much flexible access to training materials irrespective of time or place. What's more, a substantial amount of learners can be reached. Yet, as Gunasekaran et al. (2002) argue there are challenges to be faced by learners. The learning

2 László Varga, Lajos Ujváry and Tamás Németh PhD. 
social context is missing and the interaction between e-Learners and trainers/teachers are often text-based via discussion forums or e-mails. As a consequence, e-Learners often feel isolated and are sometimes also lost in the learning environment when information is presented unstructured (Wan et al. 2012; Hill et al. 2013; Fenyvesi et al. 2015).

Quite a lot of studies (Bernard et al. 2014; Chigeza-Halbert 2014; Israel 2015; Northey et al. 2015; Southard-Meddaugh-Harris 2015) compare face-to-face teaching to either online learning or blended learning in order to define the way the highest learning outcome and student satisfaction can be reached through. There is a comon understanding in them as to the fact that teaching and learning are influenced by more than the teaching format alone as many other factors play significant roles. Online learning settings are launched through learning management systems (LMS) or virtual learning environments (VLE) such as Moodle and Blackboard (Pellas-Kazanidis 2015).

Some studies (Guzzo et al. 2012; Garrison-Kanuka 2004) focus on higher education and compare the effect on students' learning outcome generated by face-to-face teaching and/or blended learning. Bernard et al. (2014) argue that students in blended programmes achieve slightly better than students following traditional classroom instruction programmes. Similar findings are made by other studies (Israel 2015; Northey et al. 2015; Southard-Meddaugh-Harris 2015; González-Gómez et al. 2016).

The way a better learning outcome can be reached is seen differently by the above studies. Whether it is the technology integration (Bernard et al. 2014), the adoption of a flipped classroom model (González-Gómez et al. 2016), or the lack of specific predictor (Israel 2015; Arbaugh et al. 2010). Some argue (Mashaw 2012) that the evaluation of blended learning is also important. Reiss and Steffens (2010) developed an evaluation model based on characteristics of the environment i. e. the combination of face-toface methods, electronic media, and corresponding strengths and weaknesses of the learning environment. They argue that an ideal mix results in synergy effects, while the abundance of electronic media saves costs but also results in the possible demotivation of learners.

Harris et al. (2009) propose a continuous evaluation of blended learning environments especially by participants. The teaching and production team should then analyze the results. The evaluation should include e.g. learning outcomes, learning style/ preferences, motivation, clarity of goals/content, perceived value and satisfaction, effectiveness and design (Sági-Tóth 2011).

Regarding learning effectiveness, several measurement models can be identified. Kirkpatrick's model (Kirkpatrick 1994, 1998) can be used for measuring learning effectiveness. Although this model is designed to evaluate trainings of corporate education, 
its four levels can be used also in higher education especially in Masters programmes (where students are employed by organisations while they study in paralel) to evaluate training: reactions (i. e. satisfaction of the learner with the training), learning (the ability of the learner to perform in new ways), behaviour (measures the job performance after the training) and organization (the extent to which training has an impact on measurable profits).

The indicators satisfaction and learning performance (also known as learning outcome), are often used together in order to measure learning effectiveness. A seemingly much subjective indicator (i. e. satisfaction) evaluates students' experience of the learning environment, while learning performance focuses on the learner from the results e. g. exam scores (Hill et al. 2013).

When designing and seting up an e-Learning programme, learning outcome will come into limelight as means of measures right after the training part (Szirmai et al. 2017). Whether they are cognitive or skill-based (describing learners' ability to use the learned knowledge and skill for solving tasks) or affective outcomes (centring round intentions to use the learning content), they all have an impact on future (work-based) performance.

Learning efficiency can be measured by different indicators. The ones used by Loukis et al. (2007) or Rasch and Schnotz's (2009) can provide a good base for that. Unlike in the corporate world, where the efficiency aspects of the learning environment are important, in higher education the focus is on pedagogical strategies and their effects on learning outcome and performance; efficiency reasons like time or cost-savings play only a secondary role.

Another adaption of the e-Learning success model of Holsapple and Lee-Post (2006) combined with Kirkpatrick's model can also be added to the basis. Whereas Kirkpatrick's model $(1994,1998)$ evaluates traditional training, Holsapple and Lee-Post (2006) concentrate on the design and delivery of the e-Learning system and its net benefits.

\section{Discussion}

\section{Planning the e-Learning platform}

The fundamentals (i. e. principles and guidance) of developing the e-Learning material was set as a stepping stone for the project in order to support partnering Universities during their preparation phase of the e-Learning base material, since a unified and harmonised concept throughout the final product was highly desired to be reached. It was 
evident that the task of creating a marketable e-Learning platform and content comprises a twofold character i. e. module leaders finalise their suggested learning and testing content on one side, and on the other the BBS Team would carry out the transformation and shaping tasks into the e-Learning framework. Thus, it was a joint interest to share a common understanding and base as only this could guarantee a problem-free and effective process. The objectives for the e-Learning panel were also specified. These were general objectives of what a student is expected to achieve when having finished the course. The e-Learning base materials (i. e. Module-based material) was ecpected to be designed in a way appropriate for reaching high-level Learning Outcomes in an e-Learning setting.

Team Budapest Business School tried its best to convert the tests sent by Module leaders into the approved visual and software supported Articulate platform taking it into account the planned timing of the 8-hour training (per module). It was made easy to create a presentation-based course in the familiar PowerPoint environment with Articulate Presenter '13. BBS e-Learning Team simply build the slides, and then added characters, quizzes, form-based interactions, web objects, and media (i. e. voice over). We also used Quizmaker to easily create the needed types of interactive assessment.

The array of elements needed in order to build a didactically strong and highbrow e-Learning material included:

(1) PPT slides (a minimum of 25)

(2) Module e-Book (appr. 25-30 pages)

(3) Glossary (a minimum of 25 definitions)

(4) Test (a minimum of 25 different types of questions)

(5) Readings (a minimum of 5 basic +5 advanced supplementary e-Books, articles etc.)

(6) Supplement (TED videos, YouTube links, filmed interviews etc.)

(7) Filmed interviews as case studies (4 interviewees from 4 companies).

Also, the expectations towards base material were highlighted and set. As to the (1) PPTs, they were expected to be based on the given Module, a slideshow in 25-30 slides was needed to be compiled by Module leaders. The slideshow had to contain texts and illustrations as well aiming at highlighting main parts of the Module e-Book, thus it would serve as a topic introduction to follow. What's more, in order to support students to acquire a deep and thorough knowledge of the four distinct Modules, each Module had to provide students with a (2) Module e-Book in appr. 25-30 pages. 
It would serve as a topic (i.e. Module) booklet for reference together with the (3) Glossary containing the most important definitions to be listed and explained in a short concise way. Fort he sake of supporting students in their self-assessment processes, (4) self-evaluation tests were included (a series of 25-30 different types of questions customized for each Module topic needs to be shaped into different kinds of, didactically proven, forms e.g. Graded questions (True/False, Multiple Choice, Multiple Response, Fill in the Blank, Matching Drag and Drop, Numeric, hotspot), Survey questions (Likert Scale, Pick One, Pick Many, Which Word, How Many) and Freeform questions (Drag and Drop, Pick One, Pick Many, Text Entry, Hotspot). For students it is of high importance to deepen knowledge according to their own needs and interest during a learning process. For that very reason, Module leaders were advised to choose 5 basic and 5 advanced, high level e-Books and/or articles as an integral part of (5) Readings and, as well as, (6) the Supplement, where relevant extra visual content that might have great potential in the learning process were selected to implant (mostly TED videos, YouTube links and/or short online interviews.) As a unique feature of former BBS eLearning programmes, (7) Filmed interviews as case studies were implemented in the FAME programme as well. The Budapest Team recorded 4 distinct interviews that contribute to the case studies as illustrations (all the interviews cover the four individual Modules and were edited into separate, well-planned parts of the programme.

The elaboration process was supported by partner meetings during the project (a total of 5 meetings were conducted with the participation of partners either on location (Budapest, Leeds, Brussels, Krakkow) or through conference calls between January 2017 and November 2018. These meetings focused around how the e-Learning platform worked, what the main features were, what could and could not be done, what information would be necessary and in what format. The requirements of the online training materials were clarified during these transnational consultation events, and also sample materials were shown in order to help participants get the feeling of what the end result would be and how students would be able to use the platform and the materials.

The development of the e-Learning materials included regular feedback occasions where the current state (content and structure) of the modules were discussed as to intro videos (featuring Module leaders), Module introduction, Learning outcomes etc. Module leaders were asked to be prepared for a video shooting i.e. introductory videos to the 4 modules with the module leaders speaking about a content summary of their modules. 
Following the blended learning approach, semester or teaching block long face-toface lectures are supported by the e-Learning materials. First, the content of the module handbooks is introduced that can be supported by the e-learning materials helping the understanding of the topics in an interactive, visualised way with self-assessment possibilities.

Figure 1: The suggested timing of e-Learning Modules

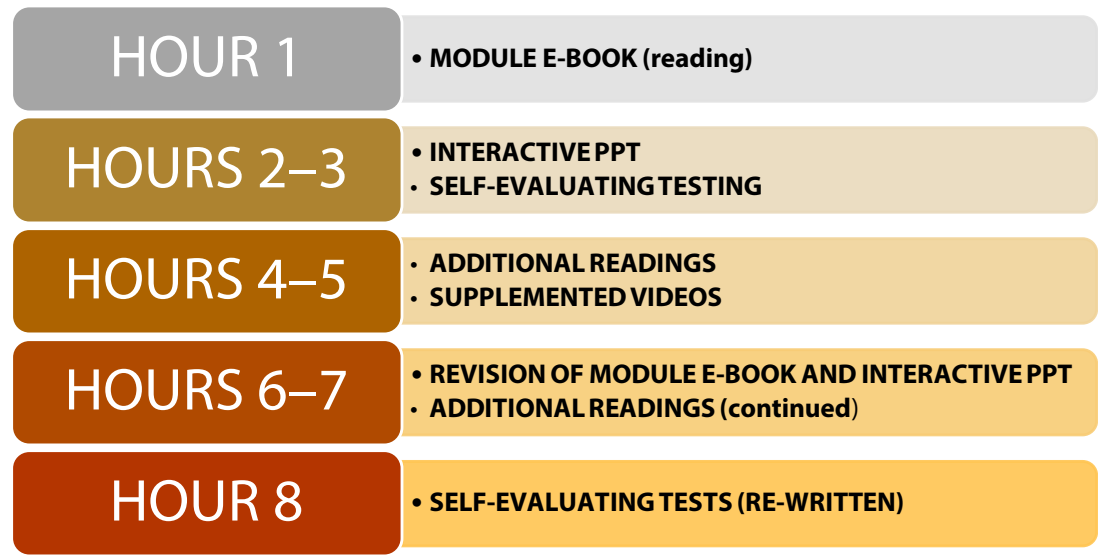

Source: own

Finally, a module-by-module evaluation of the E-learning materials was taken place during Summer 2018, where within the FAME project, some invited participants had the opportunity to use the interactive learning modules developed for the project. The FAME project team spearheaded a collaboration aiming at assessing the learning experience the participants had gained, thus set up a short questionnaire on general information (how long it took to complete the module, whether the objectives of the module were clearly defined) and some module oriented ones e.g. the structure, use, level of interactivity, content of the modules, and whether there was enough guidance in the e-Learning module on the right utilization of the content, and whether there is an adequate balance between theory and practice in the sections.

The e-Learning project team project team was interested in the personal preferences as well, so the most and less interesting/practical components were asked about, as well as comments, reamarks and suggestions were welcomed. 


\section{Summary}

In this paper we argued that the adoption of e-Learning methodology in higher education has multiple benefits, and thus it is considered among the best methods of learning and development. Several studies and authors give advantage of e-Learning as its ability to focus on the needs of both educational institutions and individual learners. For higher educational institutions, and from this respect for BBS, too, the issue of utilizing modern information and communication technologies for teaching and learning is utmostly significant. This study reviews literature and gives a scholarly background to BBS's very own e-Learning concept and protocol for FAME. We unveiled each element of design, creation, execution and adoption. A key aim of this paper was to envisage that the FAME programme was grounded in practice and is relevant to the needs of a University Master Course audience internationally. Consistent with this aim, we adopted a methodology that combined fundamental, yet modern academic, as well as business attitudes.

\section{References}

Acton, T. - Hill, S. - Scott, M. (2005): E-education - Keys to Success for Organisations, in BLED 2005 Proceedings, Paper 21. https://doi.org/10.1016/j.iree.2014.07.002.

Arbaugh, J. B. - Desai, A. - Rau, B. - Sridhar, B. S. (2010): A review of research on online and blended learning in the management disciplines: 1994-2009. Organizational Management Journal, 7, 39-55. https://doi.org/10.1057/omj.2010.5.

Bernhard, R. M. - Abrami, P. C. - Borokhovski, E. - Wade, A. - Wozney, L. - Wallet, P. A. - Fiset, M. - Huang, B. (2014): How does distance education compare with classroom instruction? A meta-analysis of the empirical literature. Review of Educational Research, (74)3, 379-439. https://doi.org/10.3102/00346543074003379.

Chigeza, P. - Halbert, K. (2014): Navigating E-Learning and Blended Learning for PreService Teachers: Redesigning for Engagement. Access and Efficiency. Australian Journal of Teacher Education, (39)11, 133-146.

https://doi.org/10.14221/ajte.2014v39n11.8.

Fenyvesi, É. - Kárpáti-Daróczi, J. - Vágány, J. B. (2015): Do we develop for the sake of development? Or what kind of training methods do leaders prefer today. Science Journal of Business and Management, (3)1-1, 59-65. 
Garrison, D. R. - Kanuka, H. (2004): Blended learning: Uncovering its transformative potential in higher education. Internet and Higher Education, (7)2, 95-105. https://doi.org/10.1016/j.iheduc.2004.02.001.

González-Gómez, D. - Jeong, J. S. - Airado Rodríguez, D. - Cañada-Cañada, F. (2016): Performance and perception in the flipped learning Model: An initial approach to evaluate the effectiveness of a new teaching methodology in a general science classroom. Journal of Science Education and Technology, (25)3, 450-459.

https://doi.org/10.1007/s10956-016-9605-9.

Graham, Ch. R. (2006): Blended learning systems: Definition, current trends, and future directions. In Bonk, C. J. - Charles R. Graham, Ch. R. (eds.): Handbook of blended learning: Global perspectives, local designs. Pfeiffer Publishing, 3-21.

Gunasekaran, A. - McNeil, R. D. - Shaul, D. (2002): E-learning: Research and applications. Industrial and Commercial Training, (34)2, 44-53.

https://doi.org/10.1108/00197850210417528.

Guzzo, T. - Grifoni, P. - Ferri, F. (2012): Social Aspects and Web 2.0 Challenges in Blended Learning. In Anastasiades, P. (ed.): Blended Learning Environments for Adults: Evaluations and Frameworks. Hershey, PA: Information Science, 35-49. https://doi.org/10.4018/978-1-4666-0939-6.ch003.

Harris, P. - Connolly, J. - Feeney, L. (2009): Blended learning: overview and recommendations for successful implementation. Industrial and Commercial Training, (41)3, 155-163. https://doi.org/10.1108/00197850910950961.

Hill, T. - Chidambaram, L. - Summers, J. (2013): A field experiment in blended learning. Performance effects of supplementing the traditional classroom experience with a web-based virtual learning environment in AMCIS 2013 Proceedings. https://doi.org/10.1080/0144929x.2016.1189964.

Holsapple, C. W. - Lee-Post, A. (2006): Defining assessing and promoting e-learning success: an information systems perspective. Decision Sciences Journal of Innovative Education, (4)1, 67-85. https://doi.org/10.1111/j.1540-4609.2006.00102.x.

Israel, M. J. (2015): Effectiveness of integrating MOOCs in traditional classrooms for undergraduate students. International Review of Research in Open and Distributed Learning (IRRODL), (16)5. https://doi.org/10.19173/irrodl.v16i5.2222.

Kirkpatrick, D. L. (1994): Evaluating Training Programs. The Four Levels. San Francisco: Berrett-Koehler.

Lewis, N. J. - Orton, P. Z. (2006): Blended learning for business impact: IBM's case for learning success. In Bonk, C. J. - Graham, C. R. (eds.): The Handbook of Blended Learning. Global Perspectives. Local Designs, San Francisco, Calif: Pfeiffer, 61-75. 
Loukis, E. - Georgiou, S. - Pazalo, K (2007): A Value Flow Model for the Evaluation of an E-Learning Service in ECIS 2007 Proceedings, Paper 175.

https://doi.org/10.1504/ijass.2009.028148.

Mashaw, B. (2012): A model for measuring effectiveness of an online course. Decision Science. Journal of Innovative Education, (10)2, 189-221.

https://doi.org/10.1111/j.1540-4609.2011.00340.x.

Northey, G. - Bucic, T. - Chylinski, M. - Govind, R. (2015): Increasing student engagement using asynchronous learning. Journal of Marketing Education, (37)3, 171-180. https://doi.org/10.1177/0273475315589814.

Pellas, N. - Kazanidis, I. (2015): On the value of Second Life for students' engagement in blended and online courses: A comparative study from the Higher Education in Greece. Education and Information Technologies, (20)3, 445-466.

https://doi.org/10.1007/s10639-013-9294-4.

Rasch, T. - Schnotz, W. (2009): Interactive and non-interactive pictures in multimedia learning environments: Effects on learning outcomes and learning efficiency. Learning and Instruction, 19, 411-422. https://doi.org/10.1016/j.learninstruc.2009.02.008.

Reiss, M. - Steffens, D. (2010): Hybrid toolboxes: Conceptual and empirical analysis of blending patterns in application of hybrid media. Technological and Economic Development of Economy, (16)2, 305-326. https://doi.org/10.3846/tede.2010.20.

Sági J. - Tóth Cs. D. (2011): Az új, moduláris rendszerű felsőfokú szakképzés szerepe a pénzügyi ismeretek terjesztésében. Erdei Ferenc VI. Tudományos Konferencia: Válságkezelés a tudomány eszközeivel. 17-54.

Singh, H. (2006): Blending Learning and Work. Real-Time Work Flow Learning. In Bonk, C. J. - Graham, C. R. (eds.): The Handbook of Blended Learning. Global Perspectives, Local Designs. San Francisco, Calif: Pfeiffer, 474-490.

https://doi.org/10.1080/02615479.2010.482983.

Southard, S. - Meddaugh, J. - France Harris, A. (2015): Can SPOC (Self-Paced Online Course) live long and prosper? A comparison study of a new species of online course delivery. Online Journal of Distance Learning Administration, 18(2).

Szirmai, A. - Csizmadia, P. - Szászvári, K. (2017): Experiences of a didactical innovation project: Training for unique skills and techniques for mentoring. In Gómez Chova, L. -López Martínez, A. - Candel Torres, I. (eds.): ICERI 2017 Proceedings. Sevilla, Spain: International Academy of Technology, Education and Development (IATED), 6501-6509. https://doi.org/10.21125/iceri.2017.1677. 
Wan, Z. - Compeau, D. - Haggerty, N. (2012): The effects of self-regulated learning processes on elearning outcomes in organizational settings. Journal of Management Information Systems, (29)1, 307-339. https://doi.org/10.2753/mis0742-1222290109. Wright, N. - Dewstow, R. - Topping, M. - Tappenden, S. (2006): New Zealand examples of blended learning. In Bonk, C. J. - Graham, C. R. (eds.): The Handbook of Blended Learning. Global Perspectives, Local Designs. San Francisco, Calif: Pfeiffer, 169-181.

This paper was written as part of the project 2016-1-HU01-KA203-022930) ERASMUS+ Strategic Partnership for Higher Education with support of the European Commission. This publication reflects only the views held by the author, and the Commission cannot be held responsible for any use which may be made of the information contained therein. 